\title{
MOLECULAR GENETIC CHARACTERIZATION OF THREE NEW KLEBSIELLA PNEUMONIAE BACTERIOPHAGES SUITABLE FOR PHAGE THERAPY
}

Gorodnichev RB $\otimes$, Kornienko MA, Kuptsov NS, Malakhova MV, Bespiatykh DA, Veselovsky VA, Shitikov EA, llina EN

Federal Research and Clinical Center of Physical-Chemical Medicine of Federal Medical Biological Agency, Moscow, Russia

The Klebsiella pneumoniae bacterium is capable of causing the broad range of human nosocomial infections associated with antibiotic resistance and high mortality. Virulent bacteriophage therapy is one of the promising alternatives to antibiotic treatment of such infections. The study was aimed to isolate virulent bacteriophages effective against the relevant clinical $K$. pneumoniae strains, and to perform the molecular genetic characterization of these phages. Bacteriophages were isolated from the river water samples using the enrichment method. The whole-genome sequencing was performed on the MiSeq platform (Illumina). Three novel K. pneumoniae bacteriophages belonging to families Autographiviridae (VB_KpnP_NER40, GenBank MZ602146) and Myoviridae (VB_KpnM_VIK251, GenBank MZ602147; vB_KpnM_FRZ284, GenBank MZ602148) have been isolated and characterized. On the collection of 105 K. pneumoniae clinical strains, it has been found that bacteriophages vB_KpnP_NER40 and vB_KpnM_VIK251 have a narrow lytic spectrum (22\% and 11\%), which is limited to strains of the capsular types K2 and K20 respectively. In contrast, bacteriophage VB_KpnM_FRZ284 has a broad lytic spectrum (37\%), causing the lysis of strains with different types of capsular polysaccharide. The phages are strictly virulent and have no genes encoding integrases, toxins or pathogenicity factors in their genomes. Genes of depolymerases, encoding the potential receptor binding proteins, have been found in the genomes of the capsular-specific bacteriophages VB_KpnP_NER40 and vB_KpnM_VIK251. The cocktail of three bacteriophages has lysed about $65 \%$ of the studied collection of $K$. pneumoniae strain and is potentially applicable for therapeutic purposes.

Keywords: virulent bacteriophages, Klebsiella pneumoniae, antibiotic resistance, phage therapy, depolymerases

Funding: the study was carried out within the framework of the State Assignment "Development of a Personalized Approach to the Therapy of Infections Using Virulent Bacteriophages" (CODE: Bacteriophage).

Acknowledgements: the authors thank the Center for Precision Genome Editing and Genetic Technologies for Biomedicine, the Federal Research and Clinical Center of Physical-Chemical Medicine of the Russian Federal Medical Biological Agency, for their help with bacteriophage genome sequencing.

Author contribution: Gorodnichev RB, Kornienko MA, Shitikov EA - study plan, data processing, manuscript writing; Kuptsov NS - data acquisition and processing, manuscript writing; Malakhova MV, Veselovsky VA — data acquisition; Bespiatykh DA — data processing, llina EN — study plan, manuscript writing. Compliance with ethical standards: experimental work was carried out in strict compliance with the guidelines SP 1.3.2322-08 "Safety of Working With Microorganisms of III-IV Groups of Pathogenicity (Danger) and Causative Agents of Parasitic Diseases"; guidelines SP 1.3.2518-09 "Additions and Amendments № 1 to the guidelines SP 1.3.2322-08 "Safety of Working With Microorganisms of III-IV Groups of Pathogenicity (Danger) and Causative Agents of Parasitic Diseases"; guidelines "Sanitary and Epidemiologic Requirements for the Handling of Medical Waste" (SanPiN 2.1.7.2790-10), and Federal Clinical Guidelines "Rational Use of Bacteriophages in Clinical and Epidemiological Practice".

$\square$ Correspondence should be addressed: Roman B. Gorodnichev

Malaya Pirogovskaya, 1a, Moscow, 119435; gorodnichev.r.b@gmail.com

Received: 21.07.2021 Accepted: 26.08.2021 Published online: 29.09.2021

DOI: 10.47183/mes.2021.035

\section{МОЛЕКУЛЯРНО-ГЕНЕТИЧЕСКАЯ ХАРАКТЕРИСТИКА ТРЕХ НОВЫХ БАКТЕРИОФАГОВ KLEBSIELLA PNEUMONIAE, ПЕРСПЕКТИВНЫХ ДЛЯ ПРИМЕНЕНИЯ В ФАГОВОЙ ТЕРАПИИ}

\author{
Р. Б. Городничев $₫$, М. А. Корниенко, Н. С. Купцов, М. В. Малахова, Д. А. Беспятых, В. А. Веселовский, Е. А. Шитиков, Е. Н. Ильина
}

Федеральный научно-клинический центр физико-химической медицины Федерального медико-биологического агентства, Москва, Россия

Бактерия Klebsiella pneumoniae способна вызывать широкий спектр внутрибольничных инфекций человека, ассоциированных с антибиотикорезистентностью и высокой смертностью. Одна из перспективных альтернатив применению антибиотиков для лечения таких инфекций - терапия вирулентными бактериофагами. Целью работы было выделить из внешней среды вирулентные бактериофраги, эффективные против актуальных клинических штаммов K. рпеитопіае, и дать их молекулярно-генетическую характеристику. Бактериофаги выделяли из проб речной воды методом накопительных культур. Полногеномное секвенирование бактериофагов выполняли на платформе MiSeq (lllumina). Выделено и описано три новых бактериофага K. pneuтопіае, принадлежащих к семействам Autographiviridae (vB_KpnP_NER40, GenBank MZ602146) и Myoviridae (vB_KpnM_VIK251, GenBank MZ602147; vB_KpnM_FRZ284, GenBank MZ602148). На коллекции из 105 клинических штаммов K. pпеuтопіае установлено, что бактериофаги vB_KpnP_NER40 и vB_KpnM_VIK251 обладают узким спектром литической активности (22\% и 11\%), ограниченным штаммами с капсульным типом К2 и К20 соответственно. Бактериофраг VB_KpnM_FRZ284, напротив, имел широкий спектр литической активности (37\%), вызывая лизис штаммов с различным типом капсульного полисахарида. Фаги обладают строго вирулентной природой и не несут в составе генома гены интеграз, токсинов или факторов патогенности. В составе геномов капсулоспецифичных бактериофагов vB_KpnP_NER40 и vB_KpnM_VIK251 обнаружены гены деполимераз, кодирующие потенциальные рецепторсвязывающие белки. Коктейль из трех бактериофагов лизировал около 65\% штаммов исследуемой коллекции К. pneumoniae и потенциально применим в терапевтических целях. Ключевые слова: вирулентные бактериофаги, Klebsiella pneumoniae, антибиотикорезистентность, фаготерапия, деполимераза Финансирование: исследование выполнено за счет средств, предоставленных для выполнения государственного задания «Разработка персонализированного подхода терапии инфекционных процессов с применением вирулентных бактериофагов» (ШИФР: Бактериофаг).

Благодарности: авторы благодарят Центр высокоточного редактирования и генетических технологий для биомедицины ФГБУ ФНКЦ ФХМ ФМБА России за секвенирование геномов бактериофагов.

Вклад авторов: Р. Б. Городничев, М. А. Корниенко, Е. А. Шитиков - план исследований, обработка данных, написание статьи; Н. С. Купцов — набор и обработка данных, написание статьи; М. В. Малахова, В. А. Веселовский - набор данных; Д. А. Беспятых - обработка данных, Е. Н. Ильина - план исследований, написание статьи.

Соблюдение этических стандартов: вся экспериментальная работа выполнена с соблюдением норм Санитарно-эпидемиологических правил «Безопасность работы с микроорганизмами III-IV групп патогенности (опасности) и возбудителями паразитарных болезней» СП 1.3.2322-08; Санитарно-эпидемиологических правил СП 1.3.2518-09 - «Дополнения и изменения № 1 к санитарно-эпидемиологическим правилам «Безопасность работы с микроорганизмами III-IV групп патогенности (опасности) и возбудителями паразитарных болезней» СП 1.3.2322-08; Санитарноэпидемиологических правил “Санитарно-эпидемиологические требования к обращению с медицинскими отходами» СанПиН 2.1.7.2790-10, а также Федеральных клинических рекомендаций «Рациональное применение бактериофагов в лечебной и противоэпидемической практике».

$\varangle$ Для корреспонденции: Роман Борисович Городничев ул. Малая Пироговская, д. 1а, г. Москва, 119435; gorodnichev.r.b@gmail.com Статья получена: 21.07.2021 Статья принята к печати: 26.08.2021 Опубликована онлайн: 29.09.2021 DOI: $10.47183 /$ mes.2021.035 
Klebsiella pneumoniae is a Gram-negative, non-motile, facultative anaerobic bacterium, widely spread in the environment. Microorganisms of this species have traditionally been regarded as commensals, they can be found on human skin, in the gastrointestinal and respiratory tract [1]. This is the second most common nosocomial pathogen in the world capable of causing a wide range of infections, such as abscesses, purulent wounds, septicemia, pneumonia, infections of urinary tract and gastrointestinal tract [2].

Inappropriate use of antibiotics all over the world resulted in emergence and spread of drug resistant bacteria. Among the members of the genus Klebsiella, the isolates, carrying genes encoding extended spectrum beta-lactamases or carbapenemase-encoding genes, are the most dangerous [3] According to the antibiotic resistance map of Russia, 30-60\% of nosocomial isolates can be resistant to carbapenems, and 60$80 \%$ can be resistant to the third generation cephalosporins [4].

As a consequence of the crisis caused by dissemination of resistant bacteria, searching for new approaches to antimicrobial therapy is especially relevant. Virulent bacteriophage (phage) therapy is one of the promising alternatives [5]. Phages are natural antagonists of bacteria in wild populations, which are capable of quick selective lysis of pathogens, including the $K$. pneumoniae isolates associated with antibiotic resistance. Phage therapy has been used in clinical practice since the early $20^{\text {th }}$ century. No significant side effects of phage therapy have been detected throughout history [6]. To date, the phage therapy safety and efficiency have been confirmed by mammal and Galleria mellonella models, as well as by clinical data $[7,8]$. The narrow host range of distinct phages is the natural limitation of this approach. As a result, phage cocktails of active bacteriophages targeting various bacterial species have to be used to combat the undefined pathogen [9].

The host range of $K$. pneumoniae phages strongly correlates with the capsular polysaccharide (CPS) type [10] To date, at least 130 CPS types have been described. CPS is the key virulence factor protecting the bacteria against the human immune system and the effects of some antibiotics [11]. Strains, characterized by the increased CPS expression, are often more virulent, and belong to the hypervirulent K. pneumoniae group [12].

The majority of $K$. pneumoniae phages encode depolymerases: the enzymes capable of breaking down the polysaccharide capsule through glycosidic bond cleavage [10, 13]. The diversity of phage depolymerases is of particular interest, since studying the enzymes may lead to developing the new class of antimicrobial agents. It has been shown that phage depolymerases can accelerate inactivation of bacteria with the serum in vitro and significantly increase the survival rate in murine and Galleria mellonella larvae models [14, 15]. Moreover, phage depolymerases can be used for the express microbial capsular type identification or the bacterial biofilm destruction [16].

The study was aimed to isolate the virulent bacteriophages, active against the relevant clinical $K$. pneumoniae strains, perform bacteriophage characterization, and assess the viability of using the bacteriophages as the agents for phage therapy.

\section{METHODS}

\section{Bacterial strains and their characteristics}

The collection of $105 \mathrm{~K}$. pneumoniae strains was compiled in 2018-2019 at the Clinical Hospital № 123 of the Federal
Research and Clinical Center of Physical-Chemical Medicine of the FMBA of Russia. All bacteria were grown in the lysogeny broth (LB) (Himedia; India) at $37^{\circ} \mathrm{C}$. The bacteria were identified by MALDI-TOF mass spectrometry as described previously [17]. Antimicrobial susceptibility was tested by the disk-diffusion method in accordance with the guidelines issued by the Clinical and Laboratory Standards Institute [18].

\section{Molecular genetic characterization of bacterial strains}

Genomic DNA was extracted using the DNA-Express kit (Lytech; Russia) following the manufacturer's instructions. Multilocus sequence typing (MLST) of $K$. pneumoniae strains was performed by sequencing of seven housekeeping genes in accordance with the standard scheme as described previously [19]. The capsular type was defined by the wzi gene Sanger sequencing [20]. Amplification of genes, included in the molecular genetic typing schemes, was carried out in the TETRAD DNA ENGINE (MJ Research; USA). Sanger sequencing was performed with the 3730 DNA Analyzer (Thermo Fisher Scientific; UK).

\section{Bacteriophage isolation and purification}

Three K. pneumoniae strains, Kp40, Kp25-1 and Kp284, were used as the hosts for bacteriophage isolation. Phages vB_KpnP_NER40, vB_KpnM_VIK251 and vB_KpnM_FRZ284 were isolated from the water samples taken from the Chermyanka River in accordance with the previously reported method [21]. The $15 \mathrm{~mL}$ river water sample was centrifuged at 10,000 $\mathrm{g}$ for $15 \mathrm{~min}$; supernatant was filtered through the $0.22 \mu \mathrm{m}$ membrane sterile syringe filter (Millipore; USA). The filtered supernatant and $0.2 \mathrm{~mL}$ of the host strain culture being in the logarithmic growth phase (OD $600 \mathrm{~nm}=0.3$ ) were combined with $15 \mathrm{~mL}$ of the double concentration LB broth and incubated overnight while stirring $(200 \mathrm{rpm})$ at $37^{\circ} \mathrm{C}$ to enrich the phage fraction. Then the culture was centrifuged at $10,000 \mathrm{~g}$ for $15 \mathrm{~min}$ and filtered through the $0.22 \mu \mathrm{m}$ filters. The resulting lysates were serially diluted in LB, the phage titer was determined by the method of agar layers according to Grazia in order to detect and isolate individual phages [22]. Monoisolates were obtained by sequential (three-fold) extraction from the distinct phage plaque.

\section{Lytic spectrum determination}

The lytic spectrum of the phages was defined by the spot test assay with the use of $105 \mathrm{~K}$. pneumoniae strains. The $100 \mu \mathrm{l}$ aliquot of the culture of each strain being in the logarithmic growth phase (OD $600 \mathrm{~nm}=0.3$ ) was added to $5 \mathrm{~mL}$ of semisolid agar (0.6\%), which was later applied on the bottom agar layer to form the top layer. Phage lysate, $5 \mathrm{~mL}$ with a titer of $10^{6} \mathrm{pfu} / \mathrm{mL}$, was applied drop by drop onto the fresh bacterial lawn and left to dry until completely absorbed. The results were assessed after the overnight incubation at $37^{\circ} \mathrm{C}$ by the presence of lysis zones at the sites of the applied bacteriophage drops. In case of solid lysis zone or sporadic phage plaques, the bacterial strain was considered sensitive to bacteriophage.

\section{Whole genome sequencing of bacteriophages and bioinformatic data analysis}

The total DNA isolation was performed using the standard phenol-chloroform extraction protocol as described previously [23]. Sequencing was carried out with the use of the MiSeq 

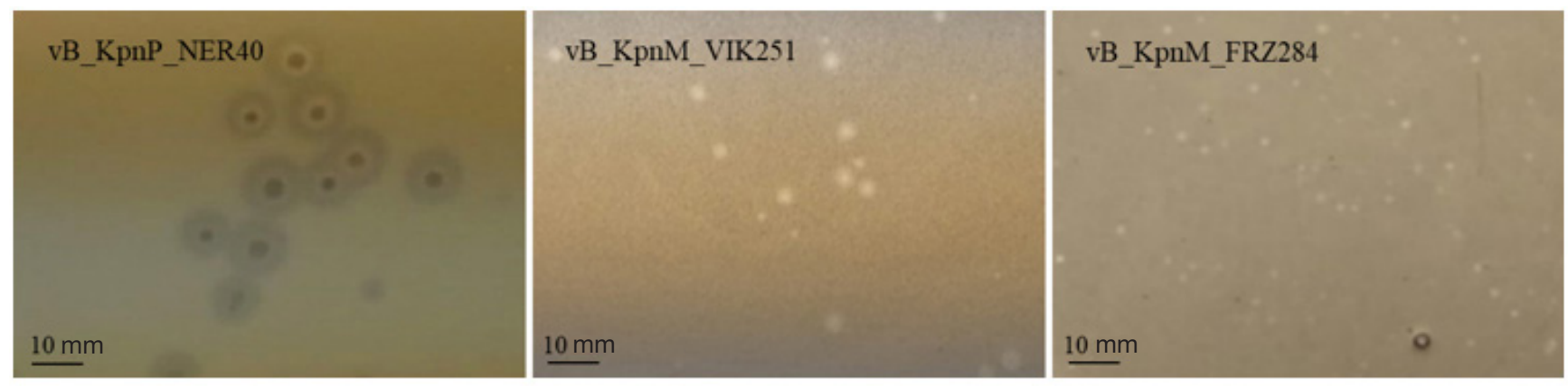

Fig. 1. Plaque morphology for the vB_KpnP_NER40, vB_KpnM_VIK251 and vB_KpnM_FRZ284 bacteriophages

tool and the MiSeq Reagent Nano Kit v2 (500 cycle) (Illumina; USA) following the manufacturer's instructions.

Genomes were assembled with the SPAdes software (v.3.14.0). Open reading frames (ORFs) were predicted using GeneMarkS (version 4.32), Phast and VGAS. The tRNAScanSE (University of California Santa Cruz, USA) and the ARAGORN (Murdoch University, Australia) software tools were used to predict the presence of transfer RNA (tRNA) in the genome. The expected functions of proteins, encoded by distinct ORFs, were predicted in the manual mode with the use of BLASTp, HHPred, Phast and InterPro. The search for genes encoding toxins and other factors in the bacteriophage genomes was performed using the pathogenic bacteria virulence factor databases [24]. Matching with the Antibiotic Resistance Gene Database was carried out in order to identify the antibiotic resistance determinants [25]. Phylogenetic analysis was performed using the amino acid sequences of RNA polymerase (for phages of Autographiviridae family) and terminase large subunit (for phages of Myoviridae family) following the guidelines issued by the International Committee on Taxonomy of Viruses (ICTV) (https://talk.ictvonline.org/taxonomy). Phylogenetic tree was constructed by the Genome-BLAST distance phylogeny method on the VICTOR web-server.
RESULTS

\section{Isolation and phenotypic characteristics of three new Klebsiella pneumoniae phages}

The Kp40 strain of $K$. pneumoniae, belonging to the sequence type (ST) 395 and capsular type K2, was used as a host strain for the vB_KpnP_NER40 phage. The Kp25-1 strain of K. pneumoniae, belonging to the ST268 and capsular type $\mathrm{K} 20$, was used as a host for isolation of vB_KpnM_VIK251 bacteriophage. The third strain of $K$. pneumoniae, Kp284, of the rare sequence type ST1655 and the undefined capsular type, was selected as a host strain for the vB_KpnM_FRZ284 phage. K. pneumoniae strains used as the host strains were resistant to three or more than three classes of antibiotics, including meropenem.

Bacteriophage vB_KpnP_NER40 formed large (3-5 mm) phage plaques, surrounded by wide halos. Plaques formed by the vB KpnM_VIK251 phage were smaller (2-3 mm), and were surrounded by small (1-2 mm) halo. Phage vB_KpnM_FRZ284 formed small $(1-2 \mathrm{~mm})$ plaques with no halo (Fig. 1). According to literary sources, hazy halo surrounding the phage plaque is associated with the supposed bacteriophage-encoded depolymerase activity [26].

Table 1. Lytic spectrum of phages vB_KpnP_NER40, vB_KpnM_VIK251 and vB_KpnM_FRZ284

\begin{tabular}{|c|c|c|c|c|}
\hline $\begin{array}{l}\text { Capsular } \\
\text { type }\end{array}$ & $\begin{array}{l}\text { Total number } \\
\text { of strains }\end{array}$ & $\begin{array}{c}\text { Number of strains lysed by } \\
\text { VB_KpnP_NER40 } \\
\text { (\% of the total number) }\end{array}$ & $\begin{array}{l}\text { Number of strains lysed by } \\
\text { vB_KpnM_VIK251 (\% of the total } \\
\text { number) }\end{array}$ & $\begin{array}{c}\text { Number of strains lysed by } \\
\text { vB_KpnM_FRZ284 } \\
\text { (\% of the total number) }\end{array}$ \\
\hline K1 & 3 & 0 & 0 & $1(33,3 \%)$ \\
\hline K2 & 25 & 23 (92\%) & 0 & $4(16 \%)$ \\
\hline K7 & 1 & 0 & 0 & $1(100 \%)$ \\
\hline K19 & 4 & 0 & 0 & $2(50 \%)$ \\
\hline K20 & 17 & 0 & $12(70,6 \%)$ & $2(11,8 \%)$ \\
\hline K23 & 6 & 0 & 0 & $3(50 \%)$ \\
\hline KL24 & 3 & 0 & 0 & $3(100 \%)$ \\
\hline KL25 & 2 & 0 & 0 & 0 \\
\hline KL38 & 1 & 0 & 0 & 0 \\
\hline KL39 & 14 & 0 & 0 & $8(57,1 \%)$ \\
\hline KL45 & 5 & 0 & 0 & $4(80 \%)$ \\
\hline K47 & 2 & 0 & 0 & 0 \\
\hline K57 & 6 & 0 & 0 & $3(50 \%)$ \\
\hline K60 & 1 & 0 & 0 & 0 \\
\hline KL62 & 1 & 0 & 0 & 1 (100\%) \\
\hline KL63 & 2 & 0 & 0 & 0 \\
\hline KL64 & 9 & 0 & 0 & $5(55,6 \%)$ \\
\hline KL107 & 1 & 0 & 0 & $1(100 \%)$ \\
\hline KL108 & 1 & 0 & 0 & 0 \\
\hline wzi475 & 1 & 0 & 0 & $1(100 \%)$ \\
\hline
\end{tabular}




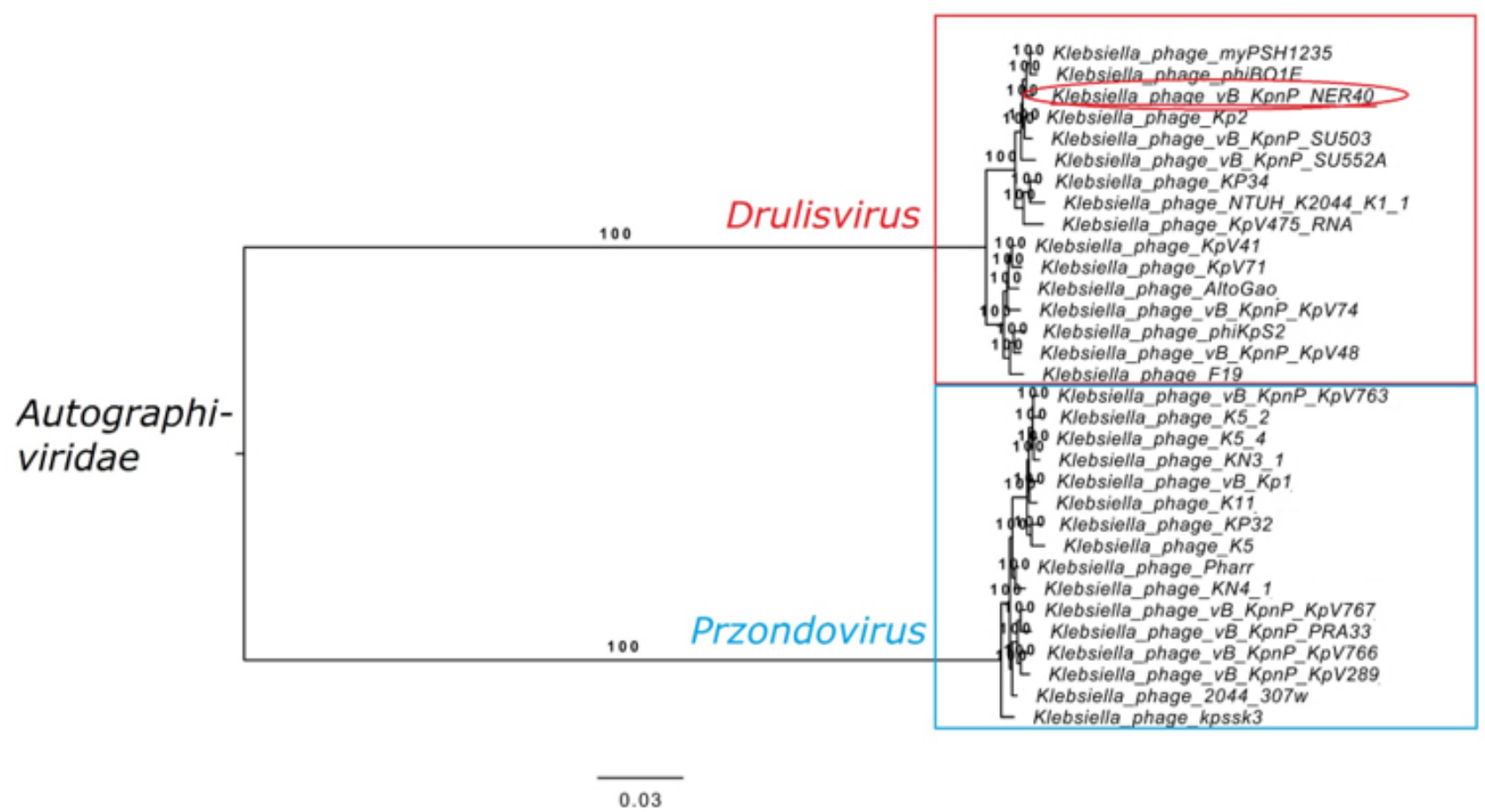

Fig. 2. Phylogeny of the Autographiviridae phage RNA polymerase amino acid sequences

\section{Lytic spectrum of bacteriophages}

The lytic spectrum of the studied phages was defined using the collection of $105 \mathrm{~K}$. pneumoniae strains. According to the results of the wzi gene sequencing, $K$. pneumoniae strains had a total of 20 unique capsular types. The most common capsular types were as follows: K2 ( $n=25 ; 23.8 \%), \mathrm{K} 20$ ( $n=17 ; 16.2 \%)$, KL39 $(n=14 ; 13.3 \%)$ and KL64 ( $n=9 ; 8.6 \%)$.

Bacteriophages vB_KpnP_NER40 and vB_KpnM_VIK251 had a narrow lytic spectrum, which was limited to strains having one capsular type (Table 1). Phage vB_KpnP_NER40 lysed 23 out of 25 strains of the capsular type $\mathrm{K} 2$, whereas phage vB_KpnM_VIK251 lysed 12 out of 17 strains with the capsular type K20. By contrast, phage vB_KpnM_FRZ284 showed lytic activity, not limited to a single capsular type. The phage lysed 39 strains from the collections having 14 different capsular types (Table 1).

\section{Analysis of bacteriophage whole-genome sequencing results}

The whole-genome sequencing with subsequent data analysis was performed for bacteriophages vB_KpnP_NER40, vB_KpnM_VIK251 and vB_KpnM_FRZ284. Annotated genome sequences were deposited into the NCBI GenBank database under the numbers MZ602146 (vB_KpnP_NER40), MZ602147 (vB_KpnM_VIK251) and MZ602148 (vB_KpnM_FRZ284).

Genome of vB_KpnP_NER40 phage was represented by double-stranded DNA and had the size of $42,674 \mathrm{bp}$. The $\mathrm{G}+\mathrm{C}$ content was $54.3 \%$. Bioinformatic analysis revealed 53 ORFs with a total length of $39,659 \mathrm{bp}$ (Table 2). Analysis of the genome nucleotide sequence using the BLASTn algorithm has shown that phage vB_KpnP_NER40 belongs to the Autographiviridae family. In order to verify the phylogenetic position of the phage, a phylogenetic tree was constructed based on the RNA polymerase amino acid sequences of the phages belonging to the Autographiviridae family, recommended by ICTV. Based on the phylogenetic analysis, phage vB_KpnP_NER40 belongs to the Drulisvirus genus of the Autographiviridae family, and seems the most closely related with the phage phiBO1E (GenBank KM576124.1; 87\% query cover and $92.05 \%$ sequence identity according to BLASTn) (Fig. 2).

The vB_KpnM_VIK251 phage genome was a linear dsDNA molecule with a length of $141,994 \mathrm{bp}$ and the $\mathrm{G}+\mathrm{C}$ content of $44.6 \%$. A total of 242 open reading frames and 23 sequences encoding tRNAs were identified. According to BLASTn, the phage matched the Myoviridae family and seemed similar to the Mydovirus genus members.

The vB_KpnM_FRZ284 phage genome was also represented by dsDNA. According to BLASTn, it belonged to the Myoviridae family. However, it seemed much more similar to the phages of the Jiaodavirus genus. The phage had a length of 166,376 bp and the $G+C$ content of $39.6 \%$, it encoded 274 open reading frames and 16 tRNAs (see Table 2).

To clarify the phylogenetic position of the Myoviridae phages, the tree was constructed based on the amino acid sequences of the terminase large subunit of phages vB_KpnM VIK251 and vB_KpnM_FRZ284, and phages, recommended by ICTV (Fig. 3). According to phylogenetic analysis, phage vB_KpnM_VIK251 belonged to the Mydovirus genus and was most closely related with the phage vB_KpnM_KB57 (GenBank KT934943.1; $87 \%$ query cover and $96.71 \%$ sequence identity according to BLASTn). Phage vB_KpnM_FRZ284 matched the phages of the Myoviridae family, genus Jiaodavirus, and seemed closely related with KPN5 (GenBank MN101229.1, 93\% query cover and $97.23 \%$ sequence identity according to BLASTn) (see Fig. 3).

\section{Functional annotation of $K$. pneumoniae phages}

When performing annotation of the phage vB_KpnP_NER40, we managed to predict the functions of 25 proteins encoded by the genome. The vB_KpnP_NER40 phage structural organization was typical for T7-like phages and was characterized by the presence of phage DNA and RNA polymerases, as well as of the lysis cassette composed by spanin-, holin- and endolysin-encoding genes located next to each other [27]. No genes encoding tRNAs, known determinants of antibiotic 


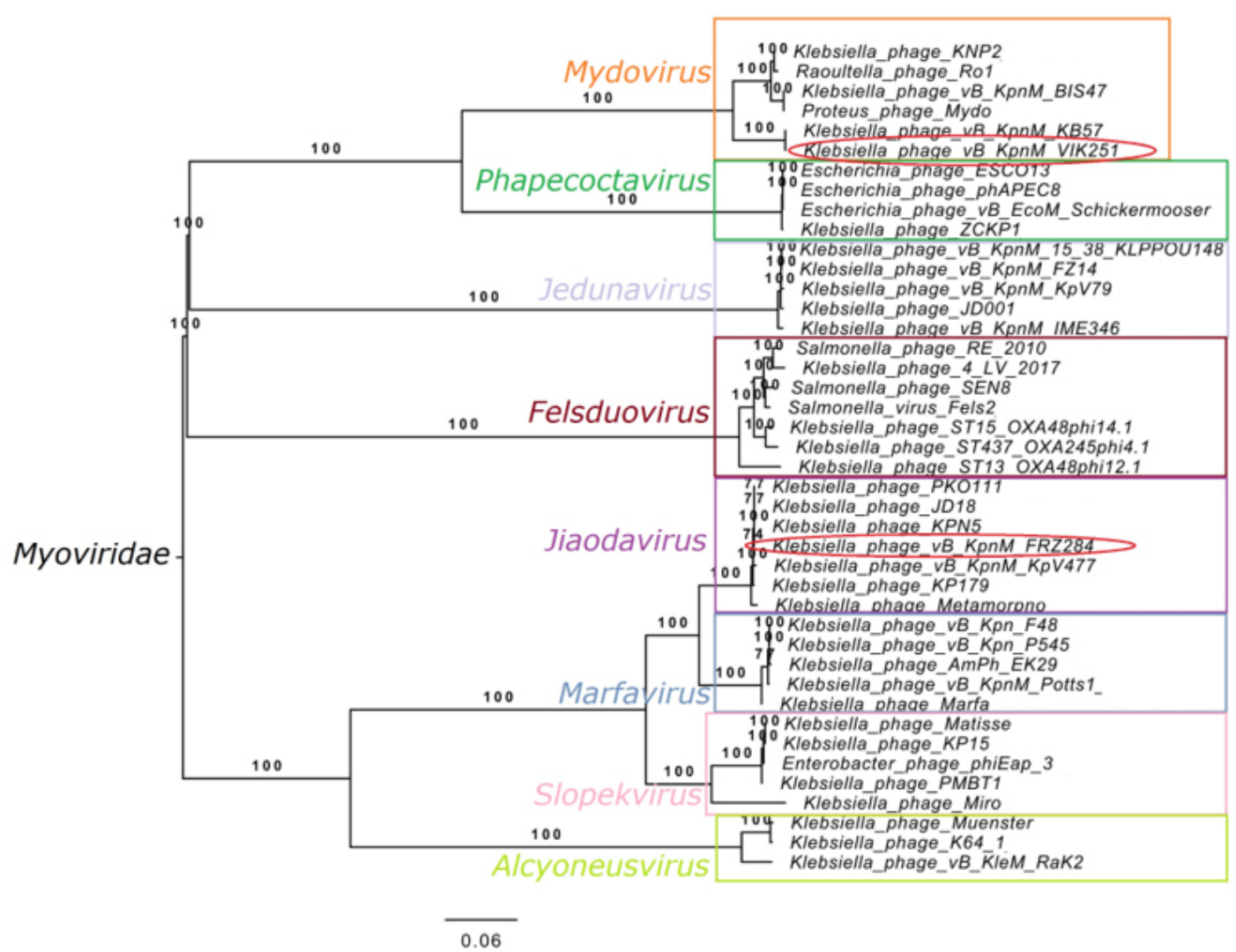

Fig. 3. Phylogeny of the Myoviridae family bacteriophage terminase large subunit amino acid sequences

susceptibility, integrases or toxins were found in the genome.

The vB_KpnP_NER40 phage genome encoded two proteins determining the host specificity: NER40_00045 and NER40_00053. The first protein, NER40_00045, has the length of 318 amino acids. It is the highly conserved protein for phages of the Drulisvirus genus. The second protein, NER40_00053, shows a high degree of homology with the tail fibers of six K. pneumoniae phages (QEQ50388.1, CAD5239035.1, QJI52632.1, YP_009789295.1, YP_009792408.1, YP_009006074.1; 96\% query cover and $98.42-97.52 \%$ sequence identity according to BLASTp). Moreover, this protein encodes the potential pectate lyase domain possessing a beta helical structure, typical for the phage-derived depolymerases.

For the vB_KpnM_VIK251 phage, the expected function (structural proteins, enzymes involved in DNA replication, regulation, transcription and translation, lysis of the host) could be attributed to the products of 145 open reading frames. No genes were found, the function of which was somehow associated with the phage lysogenic cycle. At least two genes encoding proteins homologous to the phage fibers (VIK251_00041 and VIK251_00046) were found in the genome of this phage.

The VB_KpnM_FRZ284 bacteriophage encodes 126 proteins, which could be assigned the expected function. No genes encoding integrases, toxins or any other pathogenicity factors, ruling out the therapeutic use of the phage, were found in the genome. The receptor binding proteins of this phage are represented by four proteins (FRZ284_00009, FRZ284_00012, FRZ284_00098 and FRZ284_00101) homologous to the well known proteins of the Jiaodavirus phage fibrils.

\section{DISCUSSION}

Multidrug-resistant strains of $K$. pneumoniae of the sequence types 395 and 268 and the capsular types K2 and K20 were used as the host strains for bacteriophage isolation. Such isolates are widespread, and are often associated with nosocomial outbreaks, caused by carbapenem-resistant and hypervirulent strains in Asia and Europe [28, 29].

Three new lytic phages of $K$. pneumoniae were isolated within the framework of searching for possible alternative antimicrobial therapeutic agents. Phages vB_KpnM_VIK251 and vB_KpnM_FRZ284 belonged to different genera of the Myoviridae family. Phage vB_KpnP_NER40 belonged to the Autographiviridae family. Phages vB_KpnP_NER40 and vB_KpnM_VIK251 were markedly capsule-specific (K2- and K20-specific respectively) and lysed 70-90\% strains of appropriate capsular type. In turn, vB_KpnM_FRZ284 lysed 36\% strains of the collection regardless of the capsular type.

Bacteriophage vB_KpnP_NER40 encoded depolymerase comprised in the receptor binding protein, which determined host specificity. Depolymerase of phage vB_KpnP_NER40 was homologous to several phage receptor binding proteins, including the described above K2-specific depolymerase of phage KpV74 (NC_047811.1, 96\% query cover and 98.2\% sequence identity according to BLASTp) [14].

Looking at the vB_KpnM_VIK251 bacteriophage genome more closely, one finds out that VIK251_00052 gene encodes a protein with unknown function, however, the $\mathrm{N}$-terminal region of this protein shows a high degree of homology with the tail fibril of the phage vB_KpnM_Seu621 (QOI68629.1), carrying the receptor binding depolymerase domain. Other regions of this protein encode the pectate lyase domain possesing a beta helical structure, which could be the proof of this hypothetical protein belonging to the tail fibril machinery, responsible for recognition of host receptors and depolymerase activity of this phage. The putative vB_KpnM_VIK251 phage depolymerase has no homologous proteins deposited in the NCBI database, which is a matter of great interest due to the potential of depolymerases as possible therapeutic agents targeting Klebsiella infections [15]. 
Table 2. General characteristics of vB_KpnP_NER40, vB_KpnM_VIK251 and vB_KpnM_FRZ284 phage genomes

\begin{tabular}{|c|c|c|c|c|c|}
\hline Bacteriophage & Genome, bp & G + C, \% & ORF & Family & Genus \\
\hline vB_KpnP_NER40 & 42674 & 54,3 & 53 & Autographiviridae & Drulisvirus \\
\hline vB_KpnM_VIK251 & 141994 & 44,6 & 242 & Myoviridae & Mydovirus \\
\hline vB_KpnM_FRZ284 & 166376 & 39.6 & 274 & Myoviridae & Jiaodavirus \\
\hline
\end{tabular}

To date, the mechanism of adsorption of the third phage, vB_KpnM_FRZ284, is unknown. However, broad lytic spectrum makes this phage promising for the further investigation aimed at potential expansion of the lytic spectra of other phages using the engineering approach.

When discussing the possibilities for treatment of infectious diseases caused by $K$. pneumoniae, it should be pointed out that the cocktail of the studied phages lyses $65 \%$ of the strain collection, which makes them comparable with the commercial phage-based products comprising several dozen bacteriophages in terms of efficiency [30].

\section{References}

1. Paczosa MK, Mecsas J. Klebsiella pneumoniae: going on the offense with a strong defense. Microbiology and Molecular Biology Reviews. 2016; 80 (3): 629-61.

2. Podschun R, Ullmann U. Klebsiella spp. as nosocomial pathogens: Epidemiology, taxonomy, typing methods, and pathogenicity factors. Clin Microbiol Rev. 1998; 11 (4): 589-603.

3. Lee CR, et al. Global dissemination of carbapenemase-producing Klebsiella pneumoniae: epidemiology, genetic context, treatment options, and detection methods. Frontiers in microbiology. 2016; 7: 895.

4. Kuzmenkov AY, et al. AMRmap: an interactive web platform for analysis of antimicrobial resistance surveillance data in Russia. Front Microbiol. 2021; 12: 377.

5. Górski A, et al. Phage therapy: current status and perspectives. Med Res Rev. 2020; 40 (1): 459-63.

6. Payne RJH, Jansen VAA. Phage therapy: the peculiar kinetics of self-replicating pharmaceuticals. Clin Pharmacol Ther. 2000; 68 (3): 225-230

7. Schooley RT, et al. Development and use of personalized bacteriophage-based therapeutic cocktails to treat a patient with a disseminated resistant Acinetobacter baumannii infection. Antimicrob Agents Chemother. 2017; 61 (10): e00954-17.

8. Dedrick RM, et al. Engineered bacteriophages for treatment of a patient with a disseminated drug-resistant Mycobacterium abscessus. Nat Med. 2019; 25 (5): 730-3.

9. Clark JR, March JB. Bacteriophages and biotechnology: vaccines, gene therapy and antibacterials. Trends Biotechnol. 2006; 24 (5): 212-8.

10. Pires DP, et al. Bacteriophage-encoded depolymerases: their diversity and biotechnological applications. Appl Microbiol Biotechnol. 2016; 100 (5): 2141-51.

11. Wyres $\mathrm{KL}$, et al. Identification of Klebsiella capsule synthesis loci from whole genome data. Microb genomics. 2016; 2 (12).

12. Sobirk SK, Struve C, Jacobsson SG. Primary Klebsiella pneumoniae liver abscess with metastatic spread to lung and eye, a NorthEuropean Case Report of an emerging syndrome. Open Microbiol. 2010; 4 (1): 5-7.

13. Knecht LE, Veljkovic M, Fieseler L. Diversity and function of phage encoded depolymerases. Front Microbiol. 2020; 10: 2949.

14. Solovieva EV, et al. Comparative genome analysis of novel Podoviruses lytic for hypermucoviscous Klebsiella pneumoniae of K1, K2, and K57 capsular types. Virus Res. 2018; 243: 10-18.

15. Volozhantsev N, et al. Characterization and therapeutic potential of Bacteriophage-encoded polysaccharide depolymerases with galactosidase activity against Klebsiella pneumoniae K57 capsular type. Antibiot. 2020; 9 (11): 1-16.

16. Scorpio A, et al. Treatment of experimental anthrax with
CONCLUSIONS

Bacteriophages vB_KpnP_NER40, vB_KpnM_VIK251 and vB_KpnM_FRZ284, isolated from environmental sources, have a great potential as the alternative antibacterial agents targeting the antibiotic resistant $K$. pneumoniae. Strict host specificity of phages vB_KpnM_VIK251 and vB_KpnP_NER40, as well as the capability of breaking down capsular polysaccharides and the broad lytic spectrum of phage vB_KpnM_FRZ284 make the studied phages the prospective candidates for developing highly efficient phage cocktails. recombinant capsule depolymerase. Antimicrob Agents Chemother. 2008; 52 (3): 1014.

17. Kornienko M, et al. Analysis of nosocomial Staphylococcus haemolyticus by MLST and MALDI-TOF mass spectrometry. Infect Genet Evol. 2016; 39: 99-105.

18. M100 Performance Standards for Antimicrobial Susceptibility Testing An informational supplement for global application developed through the Clinical and Laboratory Standards Institute consensus process. 29th ed. Clinical and Laboratory Standards Institute, Wayne, Pennsylvania, 2019. Available from: https://clsi. org/media/2663/m100ed29_sample.pdf.

19. Diancourt L, et al. Multilocus sequence typing of Klebsiella pneumoniae nosocomial isolates. J Clin Microbiol. 2005; 43 (8): 4178-82.

20. Brisse $S$, et al. Wzi gene sequencing, a rapid method for determination of capsular type for Klebsiella strains. J Clin Microbiol. 2013; 51 (12): 4073-8.

21. Van Twest R, Kropinski AM. Bacteriophage enrichment from water and soil. Methods Mol Biol. 2009; 501: 15-21.

22. Mazzocco A, et al. Enumeration of bacteriophages using the small drop plaque assay system. Methods Mol Biol. 2009; 501: 81-85.

23. Sambrook J, Fritsch EF, Maniatis T. Molecular cloning: a laboratory manual. 1989; 2 .

24. Liu B, et al. VFDB 2019: a comparative pathogenomic platform with an interactive web interface. Nucleic Acids Res. 2019; 47 (D1): D687-D692.

25. Liu B, Pop M. ARDB - Antibiotic Resistance Genes Database. Nucleic Acids Res. 2009; 37.

26. Wang $\mathrm{C}$, et al. Protective and therapeutic application of the depolymerase derived from a novel KN1 genotype of Klebsiella pneumoniae bacteriophage in mice. Res Microbiol. 2019; 170 (3): 156-64.

27. D'Andrea MM, et al. $\varphi \mathrm{bO} 1 \mathrm{E}$, a newly discovered lytic bacteriophage targeting carbapenemase-producing Klebsiella pneumoniae of the pandemic Clonal Group 258 clade II lineage. Sci Rep. 2017; 7 (1): 1-8.

28. Yang J, et al. A nosocomial outbreak of KPC-2-producing Klebsiella pneumoniae in a Chinese hospital: dissemination of ST11 and emergence of ST37, ST392 and ST395. Clin Microbiol Infect. 2013; 19 (11): E509-E515.

29. Muggeo A, et al. Spread of Klebsiella pneumoniae ST395 nonsusceptible to carbapenems and resistant to fluoroquinolones in North-Eastern France. J Glob. 2018; 13: 98-103.

30. Kuptsov NS, Kornienko MA, Gorodnichev RB, Danilov DI, Malakhova MV, Parfenova TV, et al. Efficacy of commercial bacteriophage products against ESKAPE pathogens. Bulletin of RSMU. 2020; (3): 18-24. 


\section{Литература}

1. Paczosa MK, Mecsas J. Klebsiella pneumoniae: going on the offense with a strong defense. Microbiology and Molecular Biology Reviews. 2016; 80 (3): 629-61.

2. Podschun R, Ullmann U. Klebsiella spp. as nosocomial pathogens: Epidemiology, taxonomy, typing methods, and pathogenicity factors. Clin Microbiol Rev. 1998; 11 (4): 589-603.

3. Lee CR, et al. Global dissemination of carbapenemase-producing Klebsiella pneumoniae: epidemiology, genetic context, treatment options, and detection methods. Frontiers in microbiology. 2016; 7: 895 .

4. Kuzmenkov AY, et al. AMRmap: an interactive web platform for analysis of antimicrobial resistance surveillance data in Russia. Front Microbiol. 2021; 12: 377.

5. Górski A, et al. Phage therapy: current status and perspectives. Med Res Rev. 2020; 40 (1): 459-63.

6. Payne RJH, Jansen VAA. Phage therapy: the peculiar kinetics of self-replicating pharmaceuticals. Clin Pharmacol Ther. 2000; 68 (3): 225-230.

7. Schooley RT, et al. Development and use of personalized bacteriophage-based therapeutic cocktails to treat a patient with a disseminated resistant Acinetobacter baumannii infection. Antimicrob Agents Chemother. 2017; 61 (10): e00954-17.

8. Dedrick RM, et al. Engineered bacteriophages for treatment of a patient with a disseminated drug-resistant Mycobacterium abscessus. Nat Med. 2019; 25 (5): 730-3.

9. Clark JR, March JB. Bacteriophages and biotechnology: vaccines, gene therapy and antibacterials. Trends Biotechnol. 2006; 24 (5): 212-8.

10. Pires DP, et al. Bacteriophage-encoded depolymerases: their diversity and biotechnological applications. Appl Microbiol Biotechnol. 2016; 100 (5): 2141-51.

11. Wyres $\mathrm{KL}$, et al. Identification of Klebsiella capsule synthesis loci from whole genome data. Microb genomics. 2016; 2 (12).

12. Sobirk SK, Struve C, Jacobsson SG. Primary Klebsiella pneumoniae liver abscess with metastatic spread to lung and eye, a NorthEuropean Case Report of an emerging syndrome. Open Microbiol. 2010; 4 (1): 5-7.

13. Knecht LE, Veljkovic M, Fieseler L. Diversity and function of phage encoded depolymerases. Front Microbiol. 2020; 10: 2949.

14. Solovieva EV, et al. Comparative genome analysis of novel Podoviruses lytic for hypermucoviscous Klebsiella pneumoniae of K1, K2, and K57 capsular types. Virus Res. 2018; 243: 10-18.

15. Volozhantsev $\mathrm{N}$, et al. Characterization and therapeutic potential of Bacteriophage-encoded polysaccharide depolymerases with galactosidase activity against Klebsiella pneumoniae K57 capsular type. Antibiot. 2020; 9 (11): 1-16.

16. Scorpio $A$, et al. Treatment of experimental anthrax with recombinant capsule depolymerase. Antimicrob Agents Chemother. 2008; 52 (3): 1014

17. Kornienko M, et al. Analysis of nosocomial Staphylococcus haemolyticus by MLST and MALDI-TOF mass spectrometry. Infect Genet Evol. 2016; 39: 99-105.

18. M100 Performance Standards for Antimicrobial Susceptibility Testing An informational supplement for global application developed through the Clinical and Laboratory Standards Institute consensus process. 29th ed. Clinical and Laboratory Standards Institute, Wayne, Pennsylvania, 2019. Available from: https://clsi. org/media/2663/m100ed29_sample.pdf.

19. Diancourt L, et al. Multilocus sequence typing of Klebsiella pneumoniae nosocomial isolates. J Clin Microbiol. 2005; 43 (8): 4178-82.

20. Brisse $\mathrm{S}$, et al. Wzi gene sequencing, a rapid method for determination of capsular type for Klebsiella strains. J Clin Microbiol. 2013; 51 (12): 4073-8.

21. Van Twest R, Kropinski AM. Bacteriophage enrichment from water and soil. Methods Mol Biol. 2009; 501: 15-21.

22. Mazzocco A, et al. Enumeration of bacteriophages using the small drop plaque assay system. Methods Mol Biol. 2009; 501: 81-85.

23. Sambrook J, Fritsch EF, Maniatis T. Molecular cloning: a laboratory manual. 1989; 2.

24. Liu B, et al. VFDB 2019: a comparative pathogenomic platform with an interactive web interface. Nucleic Acids Res. 2019; 47 (D1): D687-D692.

25. Liu B, Pop M. ARDB - Antibiotic Resistance Genes Database. Nucleic Acids Res. 2009; 37.

26. Wang $\mathrm{C}$, et al. Protective and therapeutic application of the depolymerase derived from a novel KN1 genotype of Klebsiella pneumoniae bacteriophage in mice. Res Microbiol. 2019; 170 (3): 156-64.

27. D'Andrea MM, et al. $\varphi$ bO1E, a newly discovered lytic bacteriophage targeting carbapenemase-producing Klebsiella pneumoniae of the pandemic Clonal Group 258 clade II lineage. Sci Rep. 2017; 7 (1): 1-8.

28. Yang J, et al. A nosocomial outbreak of KPC-2-producing Klebsiella pneumoniae in a Chinese hospital: dissemination of ST11 and emergence of ST37, ST392 and ST395. Clin Microbiol Infect. 2013; 19 (11): E509-E515.

29. Muggeo A, et al. Spread of Klebsiella pneumoniae ST395 nonsusceptible to carbapenems and resistant to fluoroquinolones in North-Eastern France. J Glob. 2018; 13: 98-103.

30. Купцов Н. С., Корниенко М. А., Городничев Р. Б., Данилов Д. И., Малахова М. В., Парфенова Т. В. и др. Эффективность препаратов бактериофагов против патогенов группы ESKAРЕ. Вестник РГМУ. 2020; (3): 19-26. 